J. Asiat. Soc. Bangladesh, Sci. 46(1): 13-25, June 2020

\title{
OCCURRENCE OF PROTOZOAN PARASITES OF CHANNA PUNCTATUS IN BANGLADESH
}

\author{
FATIMA NAHAR KABITA ${ }^{1}$, MD. AMINUL ISLAM BHUIYAN ${ }^{1 *}$, \\ ZANNATUN NAHAR JHINU ${ }^{1}$ AND RITA PARVEEN ${ }^{2}$ \\ ${ }^{1}$ Department of Zoology, University of Dhaka, Dhaka-1000, Bangladesh \\ ${ }^{2}$ BANBEIS, Nilkhet, Dhaka-1000, Bangladesh
}

\begin{abstract}
Three species of myxozoa (Henneguya chaudhuryi, Henneguya bengalensis and Myxobolus sp.) and 3 species of ciliophora (Trichodina pediculus, Epistylis lwoffi and Apisoma piscicolum) and two actinosporean stages of myxoza were identified. Some $51.72 \%$ of total host fishes which were found infected with at least one of the above mentioned parasites with average load of $95.93 \pm 41.53$ per infected host. High percentage (98.05) of $C$. punctatus possessed myxozoan infection and 1.95 had chiliophoran infection. The highest prevalence of parasitic infection was observed in host sample collected from Faridpur district and lowest (33.33\%) in fish sample collected from Mymensingh. The association of parasitic infection of H. bengalensis and Myxobolus sp. with study areas was found statistically significant ( $\mathrm{p}=0.024$ and 0.049 , respectively). Protozoan parasites were most abundant in gills of hosts. Shannon Diversity Index indicated that host fishes were not infested by more parasites and the parasite community was poorly diverged in all study sites. However, Simpson's Diversity showed that, parasites community was moderately diverged in host fishes collected from Mymensingh district and in rest of the areas parasite community was poorly diverged.
\end{abstract}

Key words: Protozoa parasites, Prevalence, Diversity, Channa punctatus

\section{Introduction}

Parasitic infections are the major issues causing low productivity in fish farming as well as in open water bodies (Dogiel 1961, Kayis et al. 2009). Because of its inherent difficulty in perusal compared to other larger parasitic fauna, protozoan parasite exploration has been neglected for a long time. Both ecto- and endoparasitic protozoa occupy a very important role in fish growth retardation and nutrition that most often results in multiple fish pathogenesis as being one of the hazardous threats to fish health (Enayat 2011). Most common pathogenesis can be detected as: (i) massive destruction of skin and gill epithelium of fish with internal damage and (ii) loss of appetite and ability to swim properly; sometimes it can be fatal even in the case of mild infection (Enayat 2011). Parasites generally increase in abundance and diversity in more polluted waters

*Corresponding author: aminul_zool@du.ac.bd 
which indicates the quality of the water (Poulin 1992). Apart from mortality and treatment expenses, growth retardation during disease outbreak can cause economic loss that influences against expansion of aquaculture (Omeji et al. 2011).

A considerable number of studies have been conducted on the protozoan parasites of C. punctatus in Bangladesh (Sanaullah 1996, Arthur and Ahmed 2002, Miah et al. 2013, Deb et al. 2015, Akther et al. 2018). From these studies a limited knowledge about the species identification, taxonomy, distribution and prevalence of protozoan infection was found in the host. However, precise information regarding prevalence and intensity of the protozoan parasites of this host was not mentioned. Therefore, it seems to be essential to know the current status of protozoan infestation in the wild fish of Bangladesh. The present study was an attempt to assemble a base line data of protozoan parasites of one of the important fish species, namely of Channa punctatus in Bangladesh.

\section{Materials and Methods}

Collection of host sample: The host species Channa punctatus was sampled from the freshwater bodies of Kishoreganj (Kuliar char- $24^{\circ} 10^{\prime} 40^{\prime \prime} \mathrm{N}, 90^{\circ} 50^{\prime} 57^{\prime \prime} \mathrm{E}$ ), Mymensingh

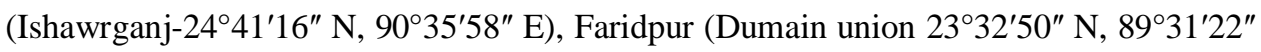
E) and Jashore (Purondorpur, Jhikorgacha Upazila- $\left.23^{\circ} 5^{\prime} 51^{\prime \prime} \mathrm{N}, 89^{\circ} 5^{\prime} 53^{\prime \prime} \mathrm{E}\right)$. A total of 29 fish specimens were collected alive with the help of fishermen from mid-April, 2018 to end of the March, 2019. Sample sizes collected from each area were not equal. However, area wise sample size was: Kishoreganj-5, Mymensingh-9, Faridpur-5 and Jashore-10 fishes.

Sample preparation and examination: Immediately after collection, the external surfaces of the fish were observed carefully using a magnifying glass. Specimens were kept moist during examination by spraying them with a fine mist of water. The collected host fishes were examined as soon as possible after capture. Samples were collected from the body slime, gill slime and blood of the host fishes which are generally the best site to colonize for protozoan parasites. Smears of body slime, gill slime and blood were placed on glass slides on the spot of collection of fishes and fixed them in ethanol solution for the observation in the Parasitology laboratory, Department of Zoology, University of Dhaka.

Klein's dry silver impregnation method: It was applied to detect the presence of ciliates in body slime and gill slime. Mucus was scraped gently off gills and skin with a scalped, spread thinly on a grease-free slide, and dry rapidly. The slide was covered with a $2 \%$

aqueous solution of silver nitrate $\left(\mathrm{AgNO}_{3}\right)$ for $8 \mathrm{~min}$. After that they were rinsed 
thoroughly with distilled water and were placed facing up in a dish of distilled water and expose to bright sunlight for 1 - 2 hours. Finally, they were allowed to dry and mount with a neutral medium, Canada balsam.

Giemsa's stain after acid hydrolysis- To detect the parasites in blood sample, the slides were stained using Giemsa stain and cover slipped by DPX mountant. During this process smears were fixed in Schaudinn's fluid and rinsed well in distilled water. After that they were hydrolysed for $8 \mathrm{~min}$ in $1 \mathrm{~N} \mathrm{HCl}$ at $>60^{\circ} \mathrm{C}$. Again, they were rinsed for several times in distilled water and stained with stocked Giemsa's stain (diluted 1:20 with water at $\mathrm{pH}$ 7.0 - 7.2) for about $20 \mathrm{~min}$ and rinsed with tap water. Then they were allowed to dry directly and finally mounted with a neutral medium, Canada balsam.

The slides were carefully examined under microscope (40x and 100x) to note the presence or absence of protozoan parasites. Counts of parasites found in selected organ were recorded. The numbers of examined parasites were counted for statistical analysis and microscopic photographs were made for identification of species with the help of 10megapixel digital camera.

Protozoans were identified according to the description of Lom and Dyková (1992), Eiras (2002), Kalavati and Nandi (2007) and Bashě and Abdullah (2010). Some parasites could not be identified up to species level (Myxobolus sp.) because these were not seemed to be matched with any of the available published description. Moreover, it appeared reasonable to make detailed observation to come to a conclusion.

Calculation: Prevalence, mean intensity and abundance of infection were calculated according to Margoles et al. (1982). Simpson's Diversity index (Simpson 1949) was used to evaluate for both richness and abundance of parasites within the samples, which was counted by the formula: $\mathrm{D}=1 / \mathrm{C}$ where, $\mathrm{C}=\sum P i^{2}\left(\mathrm{Pi}^{2}=\left(N i / N_{T}\right)^{2}\right)$; here, $P i$ is the proportional abundance of the $\mathrm{i}^{\text {th }}$ species. Shannon's Diversity index (Shannon and Weaver 1949), which measures the "information content" of a sample unit, was used to measure the diversity and it was calculated by the formula: $\mathrm{H}=-\sum_{i=1}^{S} P i \ln P i$ where, $P i$ is the proportion of individuals found in the $\mathrm{i}^{\text {th }}$ species and $\ln$ is the natural logarithm. A greater number of species and a more even distribution both increased diversity as measured by $\mathrm{H}$.

The most commonly used index of evenness is that based on the Shannon - Wiener index (Pielou 1977) which was calculated by the formula: $\mathrm{E}=\frac{H}{\ln s}$.

Margalef Index of species richness (Margalef 1958) was used to evaluate the richness of parasites species within the samples, was calculated by the formula: $\mathrm{R}=(S-1)) / \ln (n)$. 
Data analysis: Statistical analyses were carried out using Microsoft Excel 2010 and IBM SPSS version 20. Fisher's Exact test (as the sample size was small fisher exact test was done instead of Chi square test) was performed and level of significance was set at $\mathrm{p} \leq 0.05$.

\section{Results and Discussion}

During the investigation, the protozoan parasites were collected from body slime and gills but no parasites were found in blood samples of host fishes from the four study sites. A total of 1437 protozoan individuals were collected from different body parts of 15 infected C. punctatus (out of 29 fish examined). Among them 1409 (98.05\%) were Myxozoan and 28 (1.95\%) were Ciliophoran parasite. Six genera/species and two Actinosporean stages were encountered from $C$. punctatus during this study (Fig. 1). Of them there were 3 Myxozoan (Henneguya chaudhuryi, Henneguya bengalensis and Myxobolus sp.) and 3 Ciliophoran (Trichodina pediculus, Epistylis lwoffi and Apisoma piscicolum) and two Actinosporean stages of Myxozoan parasite were found (Table 1).

Among the parasites Trichodina pediculus was previously recorded in $C$. punctatus in Bangladesh (Deb et al. 2015, Akther et al. 2018). Henneguya chaudhuryi (Bajpai and Halder 1982, Chaudhary et al. 2017) and Henneguya bengalensis (Raychaudhuri and Chakravarty 1970) collected from C. punctatus were previously recorded in India but recorded as a new locality in the present study for the first time in Bangladesh (Table 2). The rest two parasite species, namely Epistylis lwoffi and Apiosoma piscicolum were recorded first in the host fish in Bangladesh (Table 2). Additionally, two Actinosporean stages of Myxozoa were found in the present study. Trichodina cyprinocola, T. pediculus, Trichodina sp., Chilodonella sp., Ichthyobodo sp., Actinophrys sp., Ichthyophthirius sp. and Myxobolus sp. were recorded from $C$. punctatus in Bangladesh in various other studies (Deb et al. 2015, Miah et al. 2013, Akther et al. 2018) and Trichodina cobitis were found from Channa striatus in Bangladesh (Asmat et al. 2017).

The Actinosporean stage of Myxozoa had not been reported as yet in C. punctatus host in this locality. Wolf and Markiw (1984) discovered that an Actinosporean (triactinomyxon) is a required alternate life cycle stage of $M$. cerebralis. Similar life cycles have now been described for around 25 species assigned to the genera Myxobolus, Henneguya, Sphaerospora, Ceratomyxa, Myxidium, Zschokkella, Theloha-nellus, Hoferellus, and Tetracapsula (Kent et al. 2001). 
Among the parasites found, Trichodina pediculus had the highest prevalence (24.14\%) and Apisoma piscicolum showed the lowest prevalence (3.45\%) (Table 3). Mean intensity of parasitic infection varied from $1.5 \pm 0.41$ to $240 \pm 62.81$ in C. punctatus (Table 3). Of
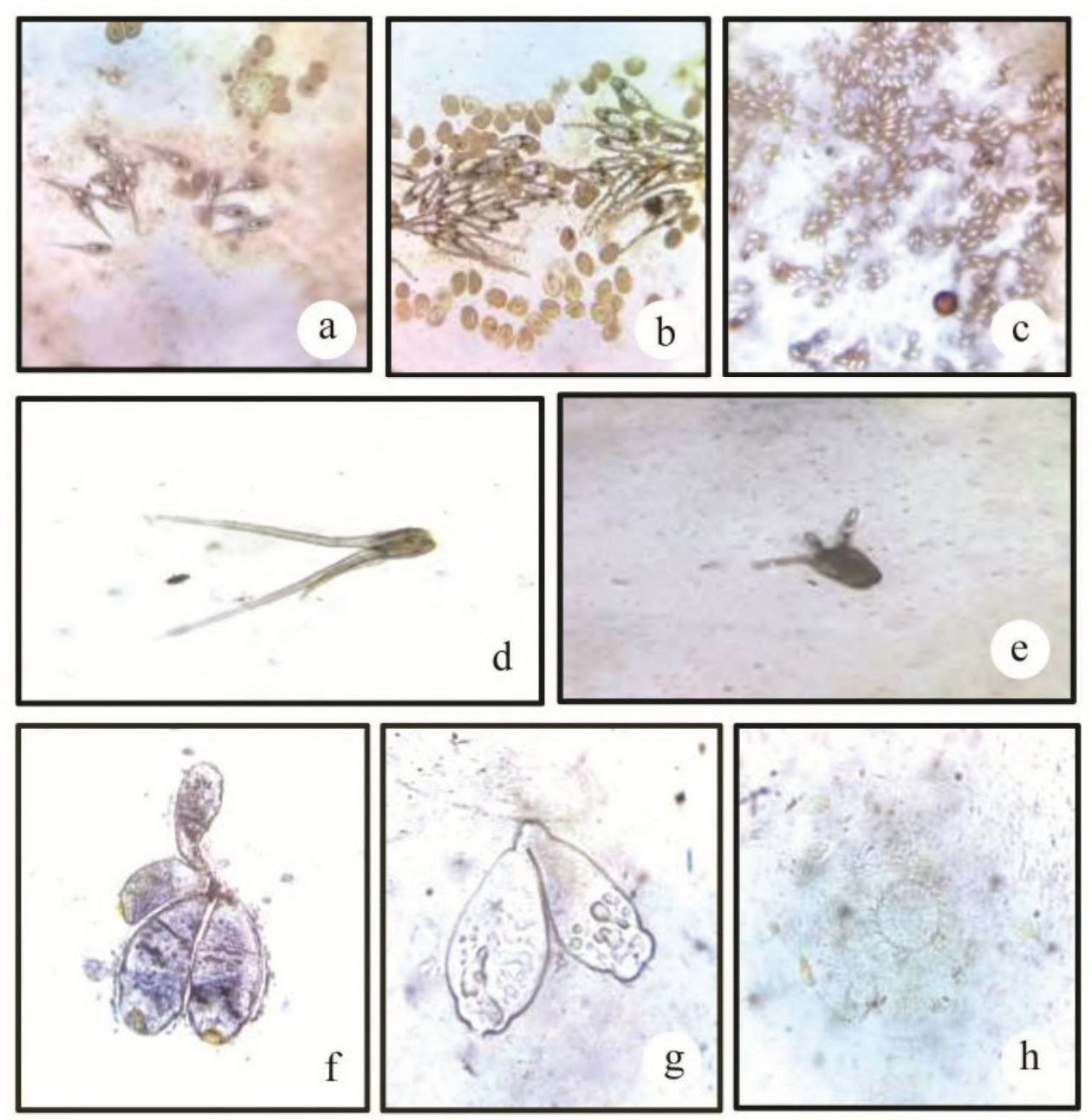

Fig. 1. Photomicrograph of different protozoan parasites. (a) $H$. bengalensis (100x), (b) $H$. chaudhuryi (100x), (c) Myxobolus sp. (100x), (d-e) Actinosporean stage of Myxozoa (observed in 100x), (f) A. piscicolum (100x), (g) E. lwoffi (40x), (h) T. pediculus (100x). Fig. a, $b, c, f=$ Stained with silver nitrate impregnation.

the parasites found in the different body parts of $C$. punctatus, Henneguya bengalensis $(55.05 \%)$ was the most abundant and Actinosporean stage showed the lowest abundance $(0.21 \%)$ (Table 3$)$. 
Chaudhary et al. (2017) reported higher prevalence (59.3\%) of $C$. punctatus infected by Henneguya chaudhuryi in India which was relatively higher in comparison with that of the present study. Deshpande and Verma (2015) reported that approximately $28.1 \%$ Channa striatus were found to be infected with Myxobolus sp. in India which was recorded higher than in this study. Deb et al. (2015) reported that almost $3.33 \%$ C. punctatus were infected by Trichodina pediculus and around 33.33\% of host fish infected

Table 1. List of protozoan parasites recorded from Channa punctatus.

\begin{tabular}{llll}
\hline $\begin{array}{l}\text { Group of } \\
\text { the parasites }\end{array}$ & Name of parasites & $\begin{array}{l}\text { Sampling } \\
\text { area }\end{array}$ & $\begin{array}{l}\text { Site of } \\
\text { infection }\end{array}$ \\
\hline \multirow{2}{*}{ Myxozoa } & $\begin{array}{l}\text { Henneguya chaudhuryi } \\
\text { Henneguya bengalensis }\end{array}$ & $\begin{array}{l}\text { Jashore } \\
\text { Myxobolus sp. }\end{array}$ & $\begin{array}{l}\text { Faridpur, Jashore } \\
\text { Kishoreganj }\end{array}$ \\
& Actinosporean stage & Mymensingh & $"$ \\
& Trichodina pediculus & Mymensingh, Faridpur, Jashore & Body slime, Gill \\
Ciliophora & Epistylis lwoffi & Faridpur, Jashore & Body slime \\
& Apiosoma piscicolum & Jashore & $"$ \\
\hline
\end{tabular}

Table 2. Updated list of protozoan parasites from Channa punctatus in this region (Bangladesh, India and Pakistan).

\begin{tabular}{ll}
\hline Parasites & References* \\
\hline Henneguya chaudhuryi $\Delta$ & Bajpai and Halder1982, Chaudhary et al. 2017, Present study \\
Henneguya bengalensis $\Delta$ & $\begin{array}{l}\text { Raychaudhuri and Chakravarty 1970, Gupta and Khera 1987, } \\
\text { Present study }\end{array}$ \\
Myxobolus sp. & $*$ \\
Actinosporean stage $\Omega \Delta$ & Present study \\
Trichodina pediculus $\S$ & Deb et al. 2015, Present study \\
Epistylis lwoffi $\Omega \Delta$ & Present study \\
Apisoma piscicolum $\Omega \Delta$ & $"$
\end{tabular}

*References of parasites identified up to genus level have not been included in this chart. $\Omega$ New host record; $\Delta$ New locality record in Bangladesh; § Previously recorded in Bangladesh.

by Trichodina cyprinocola in their study. Approximately $32.50 \%$ of C. punctatus were found to be infected with Trichodina sp. (Miah et al. 2013) in Bangladesh and interestingly Trichodinids were neither host specific nor site specific (Thilakaratine et al. 2003). Prevalence of Apiosoma sp. was recorded 8.33\% (Mofasshalin et al. 2012) 
previously in Bangladesh from skin of Cirrhinus reba but no infection status was recorded in C. punctatus in Bangladesh. Apisoma piscicolum showed a quite wide range of host variability such as Europe, Asia and South Africa (Li et al. 2007). Mixed infections of Epistylis lwoffi and Apiosoma piscicola were found in the fry of Salvelinus fontinalisin in Canada (Cone and Odense 1987). Similar findings were also recorded in the present study.

Table 3. Overall prevalence $(\%)$, mean intensity and abundance $(\%)$ of different species of protozoan parasites in $C$. punctatus.

\begin{tabular}{lcccccc}
\hline $\begin{array}{l}\text { Name of } \\
\text { parasites }\end{array}$ & \multicolumn{2}{c}{ No. of fish } & $\begin{array}{c}\text { Prevalence } \\
(\%)\end{array}$ & $\begin{array}{c}\text { Parasites } \\
\text { collected }\end{array}$ & $\begin{array}{c}\text { Mean Intensity } \\
( \pm \text { Sd })\end{array}$ & $\begin{array}{c}\text { Abundance } \\
(\%)\end{array}$ \\
\cline { 2 - 6 } $\begin{array}{l}\text { Examined } \\
\begin{array}{l}\text { Henneguya } \\
\text { chaudhuryi }\end{array}\end{array}$ & 29 & 2 & 06.90 & 480 & $240.0 \pm 62.81$ & 33.40 \\
$\begin{array}{l}\text { Henneguya } \\
\text { bengalensis }\end{array}$ & 29 & 4 & 13.79 & 791 & $197.8 \pm 85.33$ & 55.05 \\
$\begin{array}{l}\text { Myxobolus sp. } \\
\begin{array}{l}\text { Actinosporean } \\
\text { stage }\end{array}\end{array}$ & 29 & 2 & 06.90 & 135 & $67.5 \pm 22.36$ & 9.39 \\
$\begin{array}{l}\text { Trichodina } \\
\text { pediculus }\end{array}$ & 29 & 2 & 06.90 & 03 & $1.5 \pm 0.41$ & 0.21 \\
$\begin{array}{l}\text { Epistylis lwoffi } \\
\begin{array}{l}\text { Apisoma } \\
\text { piscicolum }\end{array}\end{array}$ & 29 & 7 & 24.14 & 14 & $2.0 \pm 1.02$ & 0.97 \\
\hline
\end{tabular}

In $C$. punctatus, single species of parasitic infections was found to be higher than multiple species infection at a time. In fact, $48.28 \%$ host fish had no parasitic infection. None of the host harboured more than 3 parasitic species at a time. No previous record was available on multiple infections of protozoan parasites in the host fish. However, Kaur and Katoch (2016) reported 65.15\% mixed infection of Myxozoan species at a time in native carp fish and that result was slightly similar to this study.

The occurrence of protozoan infestation also varied in different organs of fish body. During the study, the highest prevalence $(44.83 \%)$ was found in gill slime of $C$. punctatus than that of the body slime (41.38\%) (Fig. 2). This could be explained as the gills are the centre of filter feeding and the site of gaseous exchange. No parasites were found in blood sample of $C$. punctatus during this investigation. Emere and Egbe (2006) reported highest load of protozoan parasites in the gill of host species Synodontis clarias and Nyaku et al. (2007) reported highest load of protozoan parasites in the gills of 
Auchenoglanis ocidentalis, Oreochromis niloticus and Bagrus bajad in River Benue. According to Roberts and Somerville (1982), the sieving ability of the gill rakers might help to trap some organisms and this could be attributed to the presence of the protozoan parasites on that site.

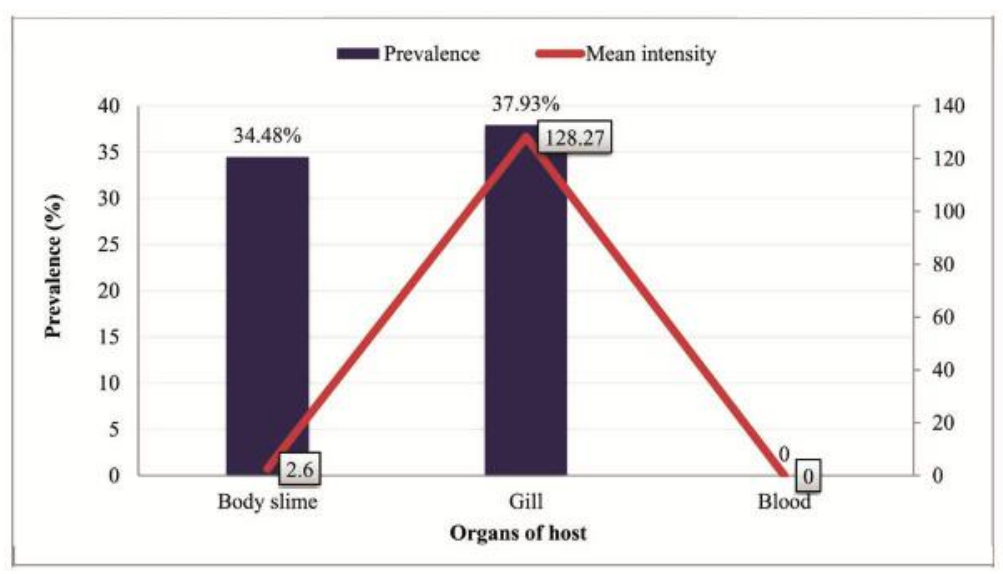

Fig. 2. Prevalence and mean intensity of parasitic infestation in organs of $C$. punctatus.

During the study, the highest prevalence (\%) of parasitic infection of $C$. punctatus observed in Faridpur (100\%) district which was followed by Jashore (50\%), Kishoregonj (40\%) and Mymensingh (33.33\%) district, respectively (Fig. 3). Fisher's Exact test showed that the association of parasitic infestation with study areas was not statistically significant $(\mathrm{p}=0.118$, since $\mathrm{p} \leq 0.05)$ in $C$. puntatus. The highest mean intensity was found in samples collected from Jashore district $(173.8 \pm 60.44)$ and lowest mean intensity (2.67 \pm 0.58 ) was found in Mymensingh district (Fig. 3).

In the present investigation, Trichodina pediculus was recorded in three study areas with highest prevalence in Faridpur (60\%) and lowest in Jashore (20\%) (Table 4). Henneguya bengalensis and Epistylis lwoffi were recorded in two study areas where highest prevalence of both parasitic species were found in Faridpur and rest of the four species were found only in one study area (Table 4). Fisher's Exact test showed that the association of parasitic infestation of Henneguya bengalensis and Myxobolus sp. with study areas was statistically significant $(\mathrm{p}=0.024$ and 0.049 , whereas $\mathrm{p} \leq 0.05)$ in $C$. punctatus. Infections of rest of parasite species with samples sites were not statistically significant. 
The site wise comparison of richness value showed that Jashore had the highest $(0.550)$ species richness in $C$. punctatus (Table 5). The lowest value was observed in Mymensingh (0.138) district (Table 5). Evenness of parasitic distribution in Mymensingh showed moderately higher value (0.955) indicated that community structure was well constructed by evenly distribution of all parasite species that was well diverged (Table 5). In Jashore (0.465) and Faridpur (0.152) had poor evenness value which meant that parasite community was poorly constructed and low diverged (Table 5). In Kishoreganj area parasite community showed no evenness, richness and diversity in $C$. punctatus because there was found only one protozoan parasite (Table 5).

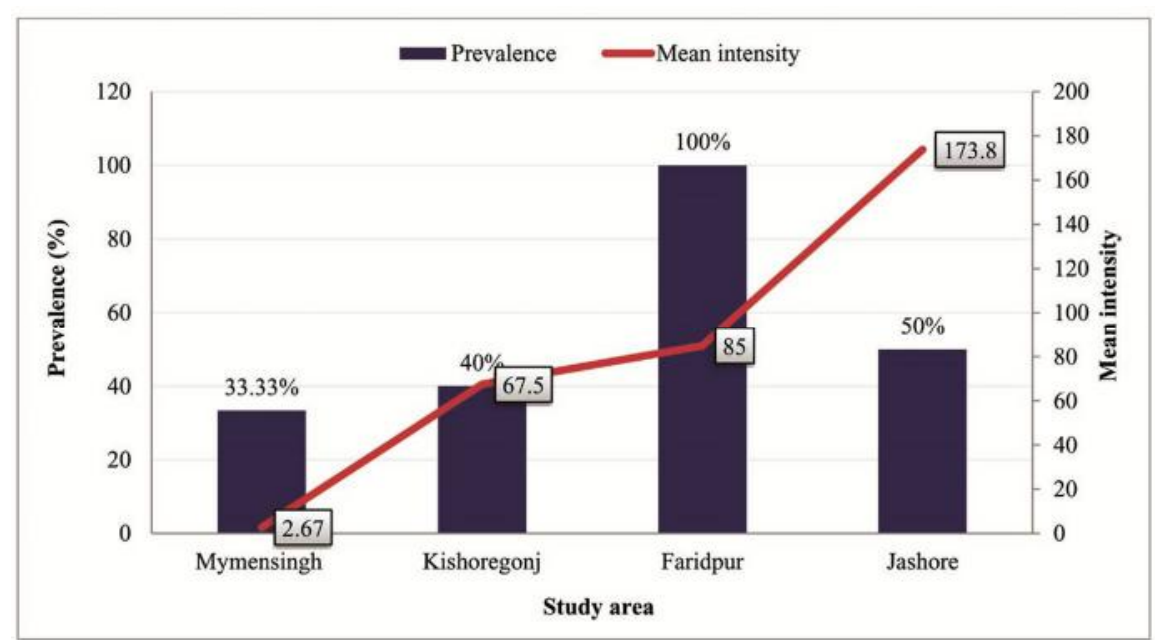

Fig. 3. Prevalence (\%) and mean intensity of protozoan parasites of $C$. punctatus in study areas.

Shannon diversity index, $\mathrm{H}=0.662,0.00,0.167$ and 0.748 in Mymensingh, Kishoreganj, Faridpur and Jashore site respectively, indicated that the sample fishes were not infested by more parasites and the parasite community were poorly diverged (Table 5). On the contrary, Simpson's diversity index, $\mathrm{D}=0.536,0.00,0.064$ and 0.504 in Mymensingh, Kishoreganj, Faridpur and Jashore site respectively, indicated that parasite community were moderately diverse in sample fishes of Mymensingh and Jashore (Table 5). Whereas, fish sample collected from Kishoreganj district had no diversity and fish samples collected from Faridpur were not infected by more parasites and parasites community were poorly diverged (Table 5). 


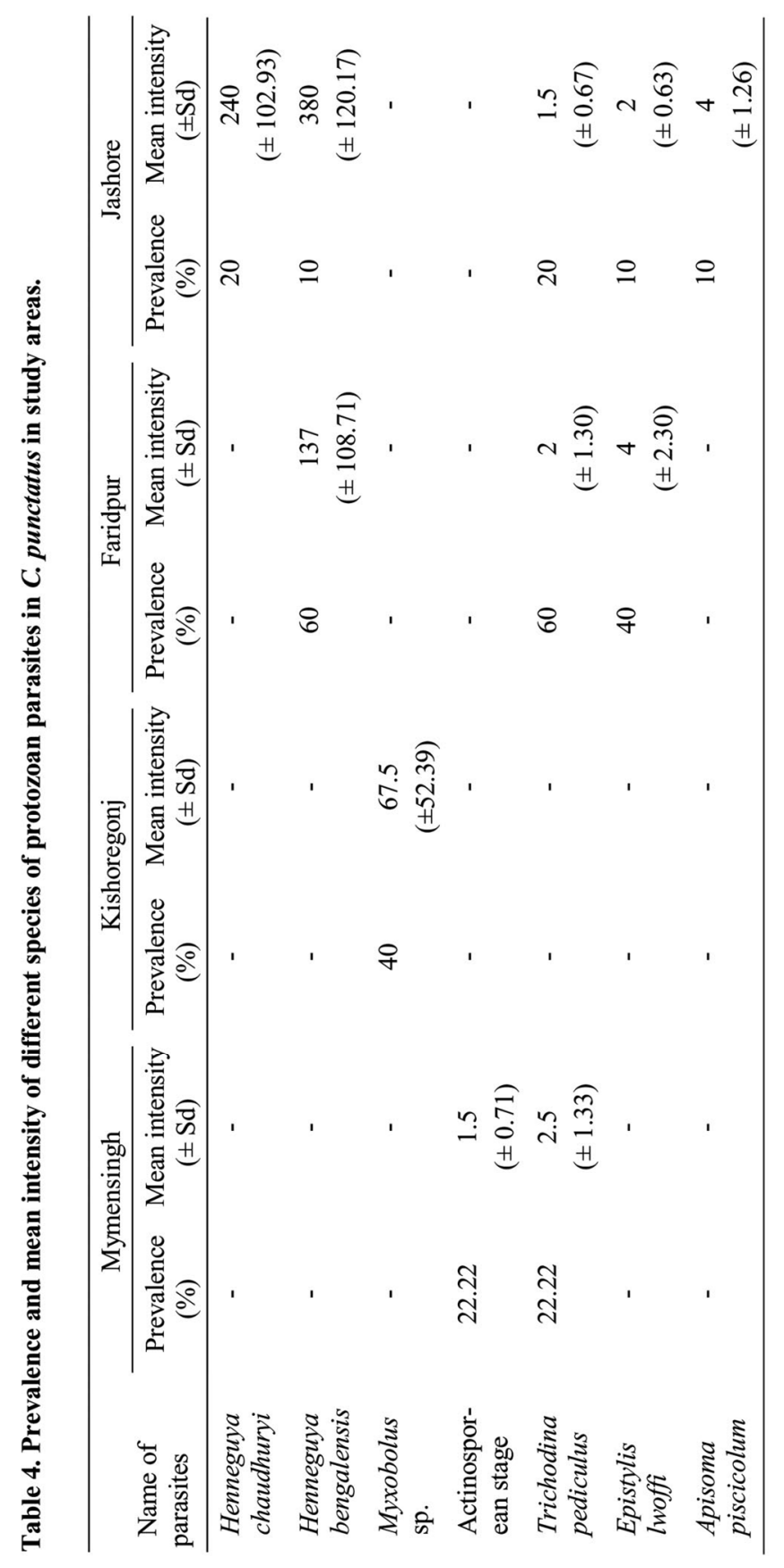


Table 5. Comparison of the richness, evenness and diversity of the parasite communities of the different sampling areas in $C$. punctatus.

\begin{tabular}{lcccc}
\hline Characteristics & Mymansingh & Kishoreganj & Faridpur & Jashore \\
\hline Number of fish examined & 09 & 05 & 05 & 10 \\
\% of fish infected & 55.56 & 40 & 100 & 50 \\
No. of parasites collected & 10 & 155 & 556 & 894 \\
No. of parasite species & 02 & 01 & 03 & 05 \\
Species evenness & 0.955 & 0.00 & 0.152 & 0.465 \\
Species of richness 'R' & 0.138 & 0.00 & 0.275 & 0.550 \\
Shannon diversity index, H & 0.662 & 0.00 & 0.167 & 0.748 \\
Simpson's diversity index, D & 0.536 & 0.00 & 0.064 & 0.504 \\
\hline
\end{tabular}

During the study, protozoan parasites exhibited variation in composition, prevalence and mean intensity in host, which might be dependent upon the factors such as parasite biology, host size, feeding habits and habitat of the host, water quality, metabolic state and weak immune system of fish. There was no previous comparative data and the cause of diversity of protozoan parasites of $C$. punctatus in the study areas. So direct comparison of the present study was not possible. There was no available data on the water quality of sample collection areas. Banerjee and Bandyopadhyay (2010) reported that water quality has a great impact on the abundance of fish pathogens and their ability to survive on host. Therefore, the reasons caused the difference of distribution of parasites in sample collecting areas could not be exactly described.

\section{Acknowledgements}

The present work was financially supported by the Ministry of Education through Bangladesh Bureau of Educational Information and Statistics (BANBEIS) and the Ministry of Science and Technology.

\section{References}

Akther, S., E. Hakkani, Ashaduzzaman and M.K. Mohanta. 2018. Prevalence of parasitic Infestations in the freshwater fish, Channa punctatus (Bloch) from Rajshahi metropolitan, Bangladesh. Int. J. Curr. Microbiol. App. Sci. 7(4): 3431-3441.

Arthur, J.R. and A.T.A. Ahmed. 2002. Checklist of the parasites of fishes of Bangladesh. Vol. 1. Food \& Agriculture Org.

Asmat, G. S., M. L. Naher, N. Sultana and M.M.A. Habib. 2017. First record of two trichodinid ectoparasites (Ciliophora: Trichodinidae) from Chittagong, Bangladesh. Journal of Biodiversity, Conservation and Bioresource Management 3(2): 11-18. 
Bajpai, R.N. and D.P. Haldar. 1982. A new myxosporidian, Unicauda chaudhuryi n. sp., (Myxozoa: Myxosporea) from the fish, Ophicephalus punctatus Bloch. Riv. Parassitol. 43(1): $147-152$

Banerjee, S. and P.K. Bandyopadhyay. 2010. Observation on prevalence of ectoparasites in carp fingerlings in two districts of West Bengal. J. Parasitic Diseases. 34(1): 44-47.

Bashě, S.K.R. and S.M.A. Abdullah. 2010. Parasitic fauna of spiny eel Mastacembelus mastacembelus from Greater Zab river in Iraq. Iranian J. Veterinary Res.11(1): 18-27.

Chaudhary, A., K. Molnár, A. Gupta, G. Cech, H.S. Singh and C. Székely. 2017. Redescription of Henneguya chaudhuryi (Bajpai \& Haldar, 1982) (Myxosporea: Myxobolidae), infecting the gills of the freshwater fish Channa punctata (Bloch) (Perciformes: Channidae) in India. Systematic Parasitology. 94(3): 403-411.

Cone, D.K. and P.H. Odense. 1987. Occurrence of Heteropolaria lwoffi (Fauré-Fremiet, 1943) and Apiosoma piscicola Blanchard, 1885 (Ciliata) on Salvelinus fontinalis (Mitchill) in Nova Scotia, Canada. Can. J. Zool. 65(10): 2426-2429.

Deb, M., F.M. Miah, M. Rahman and K.Z. Khan. 2015. Trichodinid Parasites on the Gills of Channa punctatus from the Wild and Cultured Environments in Sylhet, Bangladesh. Hindawi Publishing Corporation. Vol. 2015. 4 pages, Article ID 161562.

Deshpande, M. and R.K. Verma. 2015. Parasitic Protozoans in Some Edible Fresh Water Fishes of River Asan, District Murena. J. Adv. Lab. Res. Biol. 6(1): 12-17.

Dogiel, V.A. 1961. Ecology of the parasites of freshwater fishes. In: Parasitology of fishes. Oliver and Boyd. London. pp. 1-47.

Eiras, J.C. 2002. Synopsis of the species of the genus Henneguya Thélohan, 1892 (Myxozoa: Myxosporea: Myxobolidae. Systematic Parasitology. 52(1): 43-54.

Emere, M.C. and N.E.L. Egbe. 2006. Protozoan parasites of Synodontis clarias (A freshwater fish) in river Kaduna. Best Journal. 3(3): 58-64.

Enayat, S.A.R. 2011. A review of some ecto-and endo protozoan parasites infecting Sarotherodon Galilaeus and Tilapia zillii from Damietta Branch of River Nile, Egypt. Journal of American Science. 7(3): 362-373.

Gupta, S. and S. Khera. 1987. On the genera Henneguya Thelohan, 1892 and Unicauda, Davis, 1944. Res. Bull. (Science), Punjab University. 38(i-ii): 153-163.

Kalavati, C. and N.C. Nandi. 2007. Handbook on Myxosporean parasites of Indian fishes. Zoological Survey of India. p. 305.

Kaur, H. and A. Katoch. 2016. Prevalence, site and tissue preference of myxozoan parasites infecting gills of cultured fish in Punjab (India). Diseases of aquatic organisms. 118(2): 129137.

Kayis, S., T. Ozcelep, E. Capkin, and I. Altinok. 2009. Protozoan and metazoan parasites of cultured fish in Turkey and their applied treatments. Israeli J. Aquacult.-Bamidgeh. 61(2): 93102.

Kent, M.L., K.B. Andree, J.L. Bartholomew, M.A.N.S.O.U.R. El-Matbouli, S.S. Desser, R.H. Devlin, S.W. Feist, R.P. Hedrick, R.W. Hoffmann, J. Khattra and S.L. Hallett. 2001. Recent advances in our knowledge of the Myxozoa. J. Eukaryotic Microbiol.48(4): 395-413.

Li, M., J. Wang, J. Zhang, D. Zhu, Z. Gu and X. Gong. 2007. Observation on the Apiosoma piscicola under optical and transmission electron microscope. Acta Hydrobiologica Sinica. 31(2): 211.

Lom, J. and I. Dyková. 1992. Protozoan parasites of fishes: Developments in aquaculture and fisheries science. Elsevier, Amsterdam, Vol. 26: 315.

Margalef, R. 1958. Information theory in biology. General Systems Yearbook. 3: 36-71.

Margolis, L., G.W. Esch, J.C. Holmes, A.M. Kuris and G.A. Schad. 1982. The use of ecological terms in parasitology (report of an ad hoc committee of the American Society of Parasitologists). J. Parasitol. 68: 131-133. 
Miah, M.F., M. Deb, H. Ali, M.M.A. Quddus, and K. Ahmed. 2013. Comparative surveillance of parasitic infestation in Channa punctatus (Osteichthys: Channidae) collected from open and closed water in Sylhet, Bangladesh. Advances in Zoology and Botany 1(1): 17-23.

Mofasshalin, M. S., M. A. Bashar, M.M. Alam, G.M. Alam, D. Moumita, A.G. Mazlan and K.D. Simon. 2012. Parasites of three Indian minor carps of Rajshahi, Bangladesh. Asian J. Animal and Veterinary Advances 7(7): 613-620.

Nyaku, R.E., R.G. Okayi, O.D. Kolndadacha and M. Abdulrahman. 2007. A survey of ectoparasites associated with three (3) sp. of fish; Auchenoglanis ocidentalis, Oreochromis niloticus and Bagrus bajad in River Benue. In: Proceedings of the Annual conference of the Fisheries Society of Nigeria. pp. 10-14.

Omeji, S., S.G. Solomon and E.S. Idoga. 2011. A comparative study of the common Protozoan Parasites of Clarias gariepinus from the wild and cultured environments in Benue State, Nigeria. Journal of Parasitology Research. Vol. 2011: 8 pages, Article ID 916489.

Pielou, E.C. 1977. Mathematical Ecology. Wiley, New York.

Poulin, R. 1992. Toxic pollution and parasitism in freshwater fish. Parasitology Today 8(2): 58-61.

Raychaudhuri, S. and M.M. Chakravarty. 1970. Studies on Myxosporidia (Protozoa: Sporozoa) from the food fishes of Bengal. I. Three new species from Ophicephalus punctatus Bloch. Acta. Protozool. 8: 167-173.

Roberts, R.J. and C. Sommerville. 1982. Diseases of tilapias. In: International Conference on the Biology and Culture of Tilapias, Bellagio (Italy), 2-5 Sept. 1980.

Sanaullah, M. 1996. On the occurrence of Trypanosoma sp. (Protozoa: Kinetoplastida) in Channa punctatus (Bloch) and Anabas testudineus (Bloch) at Beel Mahmoodpur, Faridpur. Bangladesh J. Zool. 24(2): 195-198.

Shannon, C.E. and W. Weaver. 1949. The mathematical theory of communication. University Illinois Press, Urbana, Il.

Simpson, E.H. 1949. Measurement of diversity. Nature 163: 688.

Thilakaratne, I.D.S.I.P., G. Rajapaksha, A. Hewakopara, R.P.V.J. Rajapakse and A.C.M. Faizal. 2003. Parasitic infections in freshwater ornamental fish in Sri Lanka. Diseases of Aquatic Organisms. 54(2): 157-162.

Wolf, K. and M.E. Markiw. 1984. Biology contravenes taxonomy in the Myxozoa: New discoveries show alternation of invertebrate and vertebrate hosts. Science 225: 1449-1452.

(Revised copy received on 03.02.2020) 